\title{
Brief Communication: Future avenues for permafrost science from the perspective of early career researchers
}

\author{
M. Fritz ${ }^{1, a}$, B. N. Deshpande ${ }^{2,3}$, F. Bouchard ${ }^{3,4,5}$, E. Högström ${ }^{6,7}$, J. Malenfant-Lepage ${ }^{3,4,8}$, A. Morgenstern ${ }^{1}$,

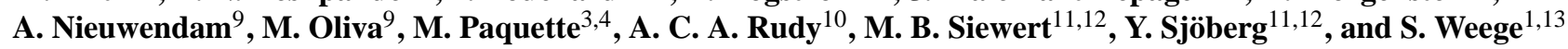 \\ ${ }^{1}$ Department of Periglacial Research, Alfred Wegener Institute, Helmholtz Centre for Polar and Marine Research (AWI), \\ 14473 Potsdam, Germany \\ ${ }^{2}$ Department of Biology, Université Laval, Quebec, QC G1V 0A6, Canada \\ ${ }^{3}$ Centre for Northern Studies (CEN), Université Laval, Quebec, QC G1V 0A6, Canada \\ ${ }^{4}$ Department of Geography, Université de Montréal, Montreal, QC H2V 2B8, Canada \\ ${ }^{5}$ Centre Eau Terre Environnement, Institut national de la recherche scientifique (INRS), Quebec, QC G1K 9A9, Canada \\ ${ }^{6}$ Department of Geodesy and Geoinformation (GEO), Vienna University of Technology (TUW), 1040 Vienna, Austria \\ ${ }^{7}$ Austrian Polar Research Institute, Vienna University, 1090 Vienna, Austria \\ ${ }^{8}$ Department of Civil and Water Engineering, Université Laval, Quebec, QC G1V 0A6, Canada \\ ${ }^{9}$ Center for Geographical Studies, Institute of Geography and Spatial Planning, Universidade de Lisboa, Lisbon, Portugal \\ ${ }^{10}$ Department of Geography, Queen's University, Kingston, ON K7L 3N6, Canada \\ ${ }^{11}$ Department of Physical Geography, Stockholm University, 10691 Stockholm, Sweden \\ ${ }^{12}$ The Bolin Centre for Climate Research, Stockholm University, 10691 Stockholm, Sweden \\ ${ }^{13}$ Institute of Earth and Environmental Science, University of Potsdam, 14476 Potsdam, Germany \\ ${ }^{a}$ currently at: Utrecht University, Department of Earth Sciences - Geochemistry, Utrecht, the Netherlands
}

Correspondence to: M. Fritz (michael.fritz@awi.de)

Received: 14 February 2015 - Published in The Cryosphere Discuss.: 25 February 2015

Revised: 12 August 2015 - Accepted: 19 August 2015 - Published: 26 August 2015

\begin{abstract}
Accelerating climate change and increased economic and environmental interests in permafrost-affected regions have resulted in an acute need for more directed permafrost research. In June 2014, 88 early career researchers convened to identify future priorities for permafrost research. This multidisciplinary forum concluded that five research topics deserve greatest attention: permafrost landscape dynamics, permafrost thermal modeling, integration of traditional knowledge, spatial distribution of ground ice, and engineering issues. These topics underline the need for integrated research across a spectrum of permafrost-related domains and constitute a contribution to the Third International Conference on Arctic Research Planning (ICARP III).
\end{abstract}

\section{Introduction}

Permafrost is a major component of the cryosphere, underlying $24 \%$ of the Northern Hemisphere's land surface (Zhang et al., 1999). Due to rapid warming in the Arctic, permafrost areas are now changing, with global implications for the carbon cycle and climate feedback mechanisms (Schaefer et al., 2012). Despite the knowledge that permafrost areas contain twice as much carbon $(\sim 1100-1500 \mathrm{Pg}$, Hugelius et al., 2014) as currently in the atmosphere and that permafrost temperatures have increased significantly during the last 2030 years (Romanovsky et al., 2010), climate projections in the IPCC Fifth Assessment Report (AR5) did not account for emissions from thawing permafrost, nor for the effects of permafrost carbon feedback on global climate. Circumpolar permafrost areas in the Arctic have been used for settlements and hunting grounds for indigenous peoples, resulting in a legacy of knowledge. Conservation of cultural heritage sites 


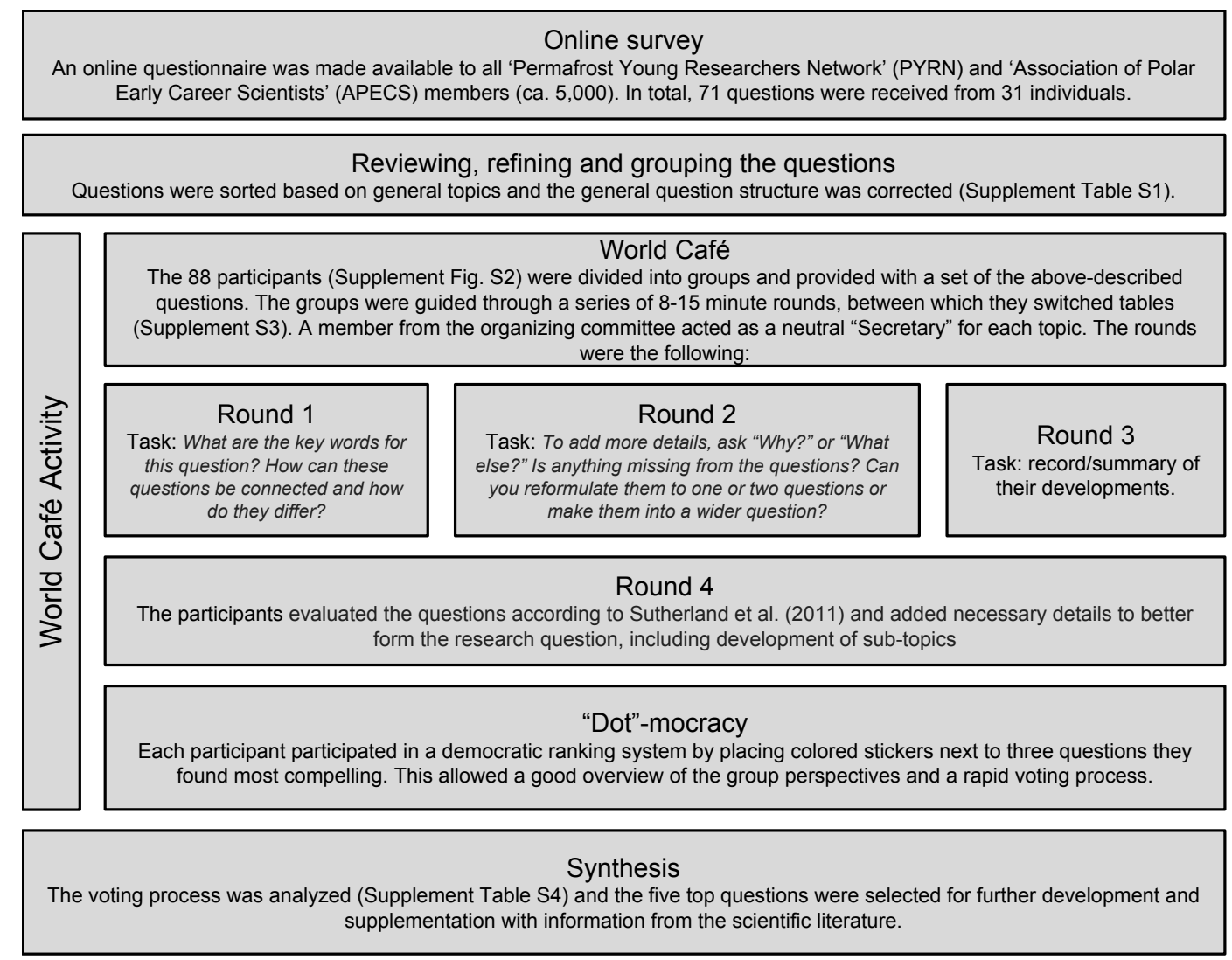

Figure 1. Flowchart of the process used to develop and refine future research questions. Questions were initially developed via an online survey. After some refinement, the process continued with an on-site "World Café" (Brown and Isaacs, 2001) workshop. Questions asked throughout the World Café enabled participants via group discussion to consider structure, breadth, and depth of the questions (Sutherland et al., 2011). Workshop participants (Fig. S2 in the Supplement) voted to identify the questions they believed to be the most compelling as a final step in the on-site activities. Based on votes, five questions were selected for further development and dissemination. The collaborative nature of the activities, coupled with substantial interest from all participating ECRs, enabled high levels of participation and thoughtful discussions about the future of permafrost research. Detailed workshop guidelines are given in Supplement S3.

and the construction of industrial and municipal infrastructures on permafrost are costly and challenging.

Over the past two decades, the International Arctic Science Committee (IASC) and the Scientific Committee on Antarctic Research (SCAR) have organized activities focused on international and interdisciplinary perspectives for advancing Arctic and Antarctic research cooperation and knowledge dissemination in many subject areas. For permafrost science, however, no consensus document exists at the international level to identify future research priorities, although the International Permafrost Association (IPA) highlighted the need for such a document during the 24th IPA Council meeting in June 2012 (IPA, 2012).

This manuscript presents the outcome of an international and interdisciplinary effort conducted by early career researchers (ECRs) in 2014. Online community input and a conference workshop have highlighted five priority research questions on the future avenues of permafrost science. This consensus statement has been formulated in collaboration with the IPA as a contribution to the Third International Conference on Arctic Research Planning (ICARP III) from ECRs in order to raise permafrost issues to the prominent position that they urgently deserve.

\section{Community consultation process}

Community input exercises are increasingly viewed as a valuable step towards elaborating future research priorities or questions in a well-defined scientific community (e.g., Kennicutt et al., 2014; Seddon et al., 2014). We aimed to meet our goals of hosting an effective large group dialogue by means of online question development followed by a "World Café" conversational process (Brown and Isaacs, 2001). This process has been continually evaluated following Sutherland et al. (2011). An overview of the process is provided in Fig. 1. This activity took place as part of an ECR workshop held prior to the 4th European Conference on Permafrost (EUCOP) in Évora, Portugal (Schollaen et 
al., 2014). Participants were provided with live instructions (Supplement S3) including criteria regarding what makes a research question (see Sutherland et al., 2011). Priority is a combination of individual criteria. However, by involving a reasonably large number of participants, the subjective reasons will move into the background and the democratically voted set of questions will remain.

\section{Breadth of questions}

Submitted questions covered a broad range of topics that focused on physical processes (32), biogeochemistry (14), social interactions and impacts (9), engineering (9), ecology (4), and modeling (3) (Table S1 in the Supplement). Of the 20 questions that received votes at the end of the World Café, 11 were associated with permafrost degradation or changes in permafrost properties (Table S4). Tied for second were the keywords "ground ice" and "carbon", which are linked to two distinct fields in permafrost research. Inter-related research topics such as "permafrost distribution", "process-related" questions, "hydrology", and "subsea permafrost" followed these three, and expressed less frequent but nonetheless important research avenues.

\section{Highlighted research questions for permafrost science}

\subsection{How does permafrost degradation affect landscape dynamics at different spatial and temporal scales? (Q1)}

Warming permafrost results in its degradation and in various interactions and feedback processes (Romanovsky et al., 2010) operating at multiple spatiotemporal scales, sometimes involving remarkable changes to landscape dynamics. While some of these regions react slowly to long-term changes, others may respond abruptly to threshold crossing (Rowland et al., 2010). Thermoerosion and mass movement can affect sediment and nutrient fluxes. Melting of ground ice and the evolution of thaw lakes will affect hydrology and water chemistry. These changes also interact with vegetation and snow cover, in a series of complex feedbacks at the ground surface and in the active layer.

More accurate knowledge on the causes and consequences of permafrost degradation will help to better assess community planning and landscape evolution models. Long-term monitoring of currently degrading sites will facilitate identification and quantification of tipping points and provide useful information on the development and recovery of the landscape. This will further enable the development of conceptual models that can help to understand the time frame, scale, and frequency at which these processes operate.

\subsection{How can ground thermal models be improved to better reflect permafrost dynamics at high spatial resolution? $(\mathbf{Q} 2)$}

In the rapidly warming Arctic, prediction of permafrost degradation is critical for providing stakeholders with the tools they need to observe and plan for future effects on the environment and human activities. From global to regional scales, a number of approaches have facilitated mapping of the ground thermal regime and its evolution over time in the past years (e.g., Westermann et al., 2013). However, on the local scale, modeling tools are either too simplistic or too complex to be used by anyone other than modeling experts to provide answers for many of the problems that Arctic communities will face in the near future. A main problem is the availability of forcing data sets at such scales, which requires permafrost modeling in conjunction with downscaling approaches (e.g., Zhang et al., 2012).

Future research should focus on identifying which processes are most important, so that models with varying levels of complexity can be developed for Arctic stakeholders. Such processes are, for example, controlled by the type and density of vegetation, snow cover, soil moisture, and human activity, which are in many cases interdependent (e.g., Painter et al., 2013). Developing model representations for these processes is amongst the most urgent challenges to improve projections on the fate of permafrost ecosystems and the carbon cycle.

\subsection{How can traditional environmental knowledge be integrated in permafrost research? $(\mathrm{Q3})$}

The circumpolar Arctic is inhabited by a variety of indigenous peoples. Having lived in close contact with nature in the Arctic for a long time, they have observed changing permafrost conditions that could provide valuable information to scientists. Traditional environmental knowledge (TEK) incorporates practice and belief and evolves by adaptive processes which are handed down through generations by cultural transmission. The highly specialized knowledge about the Arctic environment is thus preserved in the collective memory (Henry et al., 2013, and references therein).

The description of environmental processes by the nonscientific community, including indigenous peoples, often differs from that of the scientific community. This makes it challenging to incorporate TEK into existing scientific methods. Although there are examples of successful applications and integration of TEK for the purpose of co-management of natural resources (Tondu et al., 2014), increased effort is still needed to evaluate the resilience of Arctic communities (Henry et al., 2013). Successful adaptation to environmental changes demands a holistic system perspective, to which permafrost science in the case of the Arctic clearly can and should contribute. 


\subsection{What is the spatial distribution of different ground-ice types and how susceptible is ice-rich permafrost to future environmental change? $(\mathrm{Q4})$}

Ground ice is a fundamental component of permafrost soils. In the Arctic lowlands it can occupy up to $80 \%$ of the soil volume in the upper $20-30 \mathrm{~m}$ of permafrost (Brown et al., 1998). The amount of ice and its vertical and lateral distribution are central parameters controlling the thermal, physical, and geochemical properties of permafrost deposits as well as their behavior at thaw. Although many field studies characterize cryostructures, measure groundice content, and map ground-ice distribution, a concerted and organized mapping initiative that feeds into international databases is still lacking. Until now, the National Snow and Ice Data Center has been the principal database on groundice conditions, but it does not support the direct input of field-based information by international researchers. Similarly, the Global Terrestrial Network for Permafrost (GTN-P, $\mathrm{http}$ ://gtnp.arcticportal.org/) is the primary international program concerned with monitoring permafrost parameters, but it does not include or provide information on ground ice.

Efforts to address this issue should focus on remote sensing applications for landform classification and on geophysical tools and drilling for the detection of subsurface ice. Ground-ice-related information should be integrated in a dedicated database, such as GTN-P, opening the door to regional extrapolation by integrating these data into climate models.

\subsection{What is the influence of infrastructures on the thermal regime and stability of permafrost in different environmental settings? (Q5)}

Economic development in permafrost regions is facing numerous challenges since the performance of engineering structures and transportation systems is reliant on the strength of permanently frozen ground. Numerous examples exist where the combined effects of climate change and inappropriate technical solutions have led to irreversible damages or have required intensive maintenance and premature reconstruction (Bommer et al., 2010, and references therein).

National guidelines and recommendations have recently been developed to adapt infrastructures in permafrost areas (e.g., Bommer et al., 2010). Still, long-term evaluations of these practices are needed to establish reliable tools and standardized guidelines. In order to facilitate the evaluation of the construction and performance of the infrastructure in their specific environmental context, future research needs to systematically integrate permafrost engineering with Earth sciences. A main challenge is to improve predictions of the behavior and performance of structures and to act prior to the development of unstable permafrost conditions. Test sites in problematic permafrost areas are one way to address this challenge (Malenfant-Lepage et al., 2012). Overall, integrat- ing engineering knowledge with other fields of science would benefit from and contribute to the impact assessments, socioeconomic scenarios, and adaptation strategies (Vincent et al., 2013).

\section{Synthesis}

This collaborative, discussion-based consultation process allowed the community of permafrost ECRs to work out the most urgent research questions pertaining to the future of permafrost science. As such we would like to highlight research questions related to permafrost carbon and its feedback dynamics, as these are among the most popular topics in permafrost research today (Hubberten et al., 2011). Questions Q1, Q2, and Q4 are all indirectly related to carbon dynamics, and Q9, Q13, Q14, and Q16 (Table S4) directly deal with this topic. This demonstrates a specialization and fragmentation of our field as it grows rather than a lack of interest, and also a need for integration across disciplines (Vincent et al., 2013).

As the next generation of permafrost researchers, we see the need and the opportunity to participate in framing the future research priorities. Across the polar sciences, ECRs have built powerful networks, such as the Association of Polar Early Career Scientists (APECS) and the Permafrost Young Researchers Network (PYRN), which have enabled us to efficiently consult with the community. Many participants of this community-input exercise will be involved in and also affected by the Arctic science priorities during the next decade. Therefore, we need to (i) contribute our insights into larger efforts of the community such as the Permafrost Research Priorities initiative by the Climate and Cryosphere (CliC) project together with the IPA (http://www.climate-cryosphere.org/activities/ targeted/permafrost-research-priorities) and (ii) help identify relevant gaps and a suitable roadmap for the future of Arctic research. Critical evaluation of the progress made since ICARP II and revisiting the science plans and recommendations will be crucial.

IASC and the IPA, together with SCAR on bipolar activities, should coordinate the research agendas in a proactive manner engaging all partners, including funding agencies, policy makers, and local communities. Communicating our main findings to society in a dialogue between researchers and the public is a priority. Special attention must be given to indigenous peoples living on permafrost, where knowledge exchange creates a mutual benefit for science and local communities. The ICARP III process is an opportunity to better communicate the global importance of permafrost to policy makers and the public.

The Supplement related to this article is available online at doi:10.5194/tc-9-1715-2015-supplement. 
Acknowledgements. We wish to express our sincere gratitude to the workshop sponsors: IASC, the IPA, CliC, the Bolin Centre for Climate Research, the PAGE21 project (grant agreement number 282700, funded by the EC 7th Framework Programme theme FP7-ENV-2011), and the ADAPT project ("Arctic Development and Adaptation to Permafrost in Transition"). We would also like to thank the local organizers of the 4th European Conference on Permafrost at the University of Lisbon and the University of Évora (Portugal) for hosting this event. Special thanks to the numerous mentors and speakers who shared their expertise with ECRs and to Alison Cassidy, who helped with organizing the workshop. We also appreciate the comments from Nikolaus Gantner, Guy Doré, Sebastian Westermann, Scott Lamoureux, Boris Biskaborn, Hugues Lantuit, and Warwick F. Vincent regarding this manuscript. Four anonymous reviewers helped to improve the manuscript. Lastly, sincere thanks to all PYRN, APECS, ADAPT, and PAGE21 early career researchers who took part in this process. This is an official contribution to ICARP III.

Edited by: S. Gruber

\section{References}

Bommer, C., Phillips, M., and Arenson, L. U.: Practical recommendations for planning, constructing and maintaining infrastructure in mountain permafrost, Permafrost Periglac. Process., 21, 97104, doi:10.1002/ppp.679, 2010.

Brown, J. and Isaacs, D.: The World Café: Living knowledge through conversations that matter, The Systems Thinker, 12, 1-5, available at: http://www.theworldcafe.com/articles/ STCoverStory.pdf (last access: 6 January 2015), 2001.

Brown, J., Ferrians, O. J., Heginbottom, J. A., and Melnikov, E. S.: Circum-Arctic map of permafrost and ground-ice conditions, National Snow and Ice Data Center/World Data Center for Glaciology, Boulder, Colorado (revised February 2001), 1998.

Henry, C., Meakin, S., and Mustonen, T.: Indigenous perceptions of resilience. In: Arctic Resilience Interim Report 2013, Stockholm Environment Institute and Stockholm Resilience Centre, Stockholm, 2013.

Hubberten, H.-W., Lewkowicz, A. G., Christiansen, H. H., Drozdov, D. S., Ma, W., Romanovsky, V. E., and Lantuit, H.: Report from the International Permafrost Association: A new strategy and structure for the International Permafrost Association, Permafrost Periglac. Process., 22, 195-197, doi:10.1002/ppp.729, 2011.

Hugelius, G., Strauss, J., Zubrzycki, S., Harden, J. W., Schuur, E. A. G., Ping, C. L., Schirrmeister, L., Grosse, G., Michaelson, G. J., Koven, C. D., O’Donnell, J. A., Elberling, B., Mishra, U., Camill, P., Yu, Z., Palmtag, J., and Kuhry, P.: Estimated stocks of circumpolar permafrost carbon with quantified uncertainty ranges and identified data gaps, Biogeosciences, 11, 6573-6593, doi:10.5194/bg-11-6573-2014, 2014.

IPA - International Permafrost Association: Resolutions, Tenth International Permafrost Conference, 29 June 2012, Salekhard, Russia, http://ipa.arcticportal.org/publications/resolutions.html, last access: 6 January 2015.

Kennicutt II, M. C., Chown, S. L., Cassano, J. J., Liggett, D., Massom, R., Peck, L. S., Rintoul, S. R., Storey, J. W. V.,
Vaughan, D. G., Wilson, T. J., and Sutherland, W. J.: COMMENT: Six priorities for Antarctic science, Nature, 512, 23-25, doi:10.1038/512023a, 2014.

Malenfant-Lepage, J., Doré, G., and Fortier, D.: Thermal effectiveness of the mitigation techniques tested at Beaver Creek Experimental road site based on a heat balance analysis (Yukon, Canada), 15th International Conference on Cold Regions Engineering, Quebec, Canada, 42-51, 2012.

Painter, S. L., Moulton, J. D., and Wilson, C. J.: Modeling challenges for predicting hydrologic response to degrading permafrost, Hydrogeol. J., 21, 221-224, doi:10.1007/s10040-0120917-4, 2013.

Romanovsky, V. E., Smith, S. L., and Christiansen, H. H.: Permafrost thermal state in the polar Northern Hemisphere during the international polar year 2007-2009: a synthesis, Permafrost Periglac. Process., 21, 106-116, doi:10.1002/ppp.689, 2010.

Rowland, J. C., Jones, C. E., Altmann, G., Bryan, R., Crosby, B. T., Hinzman, L. D., Kane, D. L., Lawrence, D. M., Mancino, A., Marsh, P., McNamara, J. P., Romanvosky, V. E., Toniolo, H., Travis, B. J., Trochim, E., Wilson, C. J., and Geernaert, G. L.: Arctic landscapes in transition: responses to thawing permafrost, Eos Trans. Am. Geophys. Un., 91, 229-230, doi:10.1029/2010EO260001, 2010.

Schaefer, K., Lantuit, H., Romanovsky, V., and Schuur, E.: Policy implications of warming permafrost, United Nations Environment Programme (UNEP), Nairobi, Kenya, 2012.

Schollaen, K., Vieira, G., and Lewkowicz, A. G.: Report from the International Permafrost Association: Fourth European Conference on Permafrost (EUCOP4), Permafrost Periglac. Process., 25, 344-348, doi:10.1002/ppp.1828, 2014.

Seddon, A. W. R., Mackay, A. W., Baker, A. G., Birks, H. J. B., Breman, E., Buck, C. E., Ellis, E. C., Froyd, C. A., Gill, J. L., Gillson, L., Johnson, E. A., Jones, V. J., Juggins, S., Macias-Fauria, M., Mills, K., Morris, J. L., Nogues-Bravo, D., Punyasena, S. W., Roland, T. P., Tanentzap, A. J., Willis, K. J., Aberhan, M., van Asperen, E. N., Austin, W. E. N., Battarbee, R. W., Bhagwat, S., Belanger, C. L., Bennett, K. D., Birks, H. H., Ramsey, C. B., Brooks, S. J., de Bruyn, M., Butler, P. G., Chambers, F. M., Clarke, S. J., Davies, A. L., Dearing, J. A., Ezard, T. H. G., Feurdean, A., Flower, R. J., Gell, P., Hausmann, S., Hogan, E. J., Hopkins, M. J., Jeffers, E. S., Korhola, A. A., Marchant, R., Kiefer, T., Lamentowicz, M., Larocque-Tobler, I., Lopez-Merino, L., Liow, L. H., McGowan, S., Miller, J. H., Montoya, E., Morton, O., Nogue, S., Onoufriou, C., Boush, L. P., Rodriguez-Sanchez, F., Rose, N. L., Sayer, C. D., Shaw, H. E., Payne, R., Simpson, G., Sohar, K., Whitehouse, N. J., Williams, J. W., and Witkowski, A.: Looking forward through the past: identification of 50 priority research questions in palaeoecology, J. Ecol., 102, 256-267, doi:10.1111/1365-2745.12195, 2014.

Sutherland, W. J., Fleishman, E., Mascia, M. B., Pretty, J., and Rudd, M. A.: Methods for collaboratively identifying research priorities and emerging issues in science and policy, Meth. Ecol. Evol., 2, 238-247, doi:10.1111/j.2041210X.2010.00083.x, 2011.

Tondu, J. M. E., Balasubramaniam, A. M., Chavarie, L., Gantner, N., Knopp, J. A., Provencher, J. F., Wong, P. B. Y., and Simmons, D.: Working with northern communities to build collaborative research partnerships: perspectives from early career researchers, Arctic, 67, 419-429, doi:10.14430/arctic4416, 2014. 
Vincent, W. F., Lemay, M., Allard, M., and Wolfe, B. B.: Adapting to permafrost change: A science framework, Eos Trans. Am. Geophys. Un., 94, 373-375, doi:10.1002/2013EO420002, 2013.

Westermann, S., Schuler, T., Gisnås, K., and Etzelmüller, B.: Transient thermal modeling of permafrost conditions in Southern Norway, The Cryosphere, 7, 719-739, doi:10.5194/tc-7-7192013, 2013.

Zhang, T., Barry, R. G., Knowles, K., Heginbottom, J. A., and Brown, J.: Statistics and characteristics of permafrost and ground-ice distribution in the Northern Hemisphere, Polar Geogr., 23, 132-154, doi:10.1080/10889379909377670, 1999.
Zhang, Y., Li, J., Wang, X., Chen, W., Sladen, W., Dyke, L., Dredge, L., Poitevin, J., McLennan, D., Stewart, H., Kowalchuk, S., Wu, W., Kershaw, P., and Brook, R. K.: Modelling and mapping permafrost at high spatial resolution in Wapusk National Park, Hudson Bay Lowlands, Can. J. Earth Sci., 49, 925-937, doi:10.1139/e2012-031, 2012. 